\title{
Drømmen møder virkeligheden: Når en sammenhængende filosofi ikke er nok til at være effektiv i professionel fodbold
}

\section{Carsten Hvid Larsen}

Syddansk Universitet, Danmark

\section{Resumé}

Professionel fodbold handler at drive en forretning og det primære fokus for professionelle klubber er at opnå gode resultater og at vinde den næste kamp. At integrere sportspsykologi er en langvarig proces og for at være succesfuld i professionel sport, er der et behov for et stabilt miljø. For at sportspsykologiske konsulenter er effektive i professionelle sportsorganisationer, er der behov for at forstå forskellige niveauer af organisationskultur som de indgår i. Denne artikel beskriver et sportspsykologisk program i en dansk professionel fodboldklub. Jeg forsøger undervejs at illustrere nødvendigheden af at integrere selvrefleksion og kulturel sensitivitet som en del af den sportspsykologiske konsulents tilgang til at implementere sportspsykologi i professionel fodbold.

Nøgleord: Fodbold, anvendt sportspsykologi, elitesport, teamsport, organisatorisk psykologi mangler

I denne artikel deler jeg mine oplevelser omkring at udvikle og implementere et sportspsykologisk program i en dansk professionel fodboldklub. Da jeg startede med at arbejde i klubben, arbejdede jeg ud fra en systematisk og sammenhængende professionel filosofi. I midlertid indså jeg, i løbet af min tid i den professionelle fodboldklub, at en sammenhængende filosofi måske ikke var nok til at være effektiv i en professionel sportsorganisation. For at sportspsykologiske konsulenter kan være effektive i professionelle sportsorganisationer, har de brug for at forstå forskellige niveauer af organisationskultur. På nuværende tidspunkt forstår jeg de multikulturelle forskelle $i$ en professionel sportsorganisation, og hvordan kultur påvirker den sportspsykologiske konsulents ydelser. Jeg ønsker at dele mine refleksioner og erfaringer med andre for at undgå at samme fejl gentages. Jeg er en del af Team Danmark. Min uddannelsesmæssige baggrund omfatter 10 års erfaring som sportspsykologisk konsulent og en Ph.d. i sportspsykologi. Jeg har arbejdet med flere forskellige holdsport (fodbold, håndbold og ishockey) på nationalt og internationalt niveau. Før programmet blev igangsat spændte min erfaring fra at arbejde med første og anden divisionshold (fra fire til seks måneder) og til at yde individuel konsultation ( $\mathrm{i}$ et til to år) til spillere fra den danske Superliga. Yderligere har jeg arbejdet med individuelle sportsgrene (f.eks. tennis, svømning, badminton, taekwondo, handicapsport, cykling, atletik og cricket) på nationalt niveau og har forberedt atleter på at indtræde i verdensmesterskaber og Olympiske Lege.

Professionelle sportsorganisationer skal konstant skabe resultater og udvikle stjernespillere for at tilfredsstille krævende eksterne interessenter som fans, medierne og sponsorer (Mielke, 2007), og for at forretningen kan opnå dens kort- og langsigtede mål (Cruickshank \& Collins, 2012). Et af kravene til sportsorganisationerne er internt at forny ledelsen og strukturen for at opfylde behovene fra eksterne kunder (Moran \& Brightman, 2001). Det primære fokus for professionelle klubber er at opnå gode resultater og at vinde den næste kamp, og derved leve op til forventningerne fra sponsorerne og medierne (Storm, 2012). Denne kortsigtede tilgang står til tider i kontrast til at arbejde med sportspsykologi, hvor udvikling af atleter er en langvarig proces. Når en bestyrelse mener, at trænerens arbejde ikke er godt nok til at opnå organisationens målsætninger (dvs. middelmådige resultater) er udviklingen og implementeringen af tiltag og løsninger, i modsætning til andre domæner, normalt ikke internt drevet (Cruickshank \& Collins, 2012). Som følge heraf udvikles ofte en "hyrings og fyrings"-politik, når cheftræneren, som er ansvarlig for holdets præstationer på banen, mislykkes med at levere de forventede resultater (Cruickshank \& Collins, 2012). Et billede på professionelle klubbers "kortsigtedhed" er engelsk fodbold, hvor "holdbarheden" på cheftrænere er rekordlave 1,40 år (Cruickshank \& Collins, 2012) og i den Danske Superliga 1,46 år (Tipsbladet, 2016). Ud fra perspektivet om at levere sportspsykologi til talentfulde atleter, er et langsigtet fokus og et stabilt miljø (og organisation) forudsætninger for succes (Henriksen, Stambulova \& Roessler, 2010). Imidlertid påvirker en "kortsigtet tilgang" i sport generelt, og særligt i fodbold (dvs. et behov for at vinde, undgå nedrykning og at overleve for enhver pris), konsulentens ydelser og efterfølgende organisationens driftskultur (Nesti, Littlewood, O'Halloran, Eubank, \& Richardson, 2012). For at enhver klub eller organisation kan forsætte med at være 


\section{Sport and Exercise Psychology}

konkurrencedygtig, er der behov for at anerkende spillernes ressourcer og psykologiske færdigheder som nøglefaktorer for udvikling og præstation. Tilsyneladende er der en mangel på viden og en skepsis over for sportspsykologi, uklare beskrivelser af ydelser, og problemer med at integrere sportspsykologi på holdet (Johnson, Anderson, \& Fallby, 2011), som påvirker integrationen af sportspsykologiske konsulenter i højpræstations organisationer. Johnson et al. (2011) forklarede: "Nogle trænere italesatte en frygt for og negative opfattelser af sportspsykologiske konsulenter pga. forkert forudgående viden om sportspsykologiens potentiale, så som at opfatte det som 'nonsens' eller som kun at være afslapningstræning i omklædningsrummet" (s.305). Britisk forskning viste tilsvarende, at sportspsykologiske konsulenter ofte (og fejlagtigt) anses som problemløsere, i modsætning til "arkitekter for langsigtede psykologisk udvikling af atleter" (Harwood \& Steptoe, 2013, s. 169).

\section{Organisationskulturens rolle i elitesport}

For at sportspsykologiske konsulenter kan være effektive i en sportsorganisation, er det nødvendigt, at de forstår forskellige niveauer af organisationskultur (Fletcher \& Wagstaff, 2009). Ekspertise med at skabe og bibeholde en præstationskultur er en nøgleopgave i den sportspsykologiske service (Fletcher \& Arnold, 2011). I midlertid har der været begrænset med opmærksomhed på faktorer forbundet med optimal organisationsfunktion i sport. Fletcher og Wagstaff (2009) hævder, at der eksisterer et område, der endnu ikke er afdækket, hvad angår hvordan individet og holdet interagerer med den bredere organisation og for at "opnå og bibeholde succesfulde resultater er det nødvendigt at organisationen er effektivt og kompetent ledet" (s.427). Studier omhandlende organisationspsykologi i sport antyder, at arbejde indenfor et miljø indebærer at yde service, hvor der er mange forstyrrende elementer, såsom organisatorisk spænding eller frygt, forandringer, pres, eksterne krav, medieindblanding, kontraktforhandlinger og sportsagenter (Nesti, 2010). Yderligere fremhæver forskere, at efter organisatoriske ændringer følger der ofte dårligt arbejdsklima der direkte eller indirekte påvirker præstationerne på banen (Wagstaff \& Larner, 2015).

\section{Professionel filosofi}

Ifølge den moderne forsker-praktikker model, kan en praktiker opfattes som en forsker, der baserer sine ydelser på teori, idet han eller hun laver vurderinger af problemer og beslutter sig for en strategi for at løse dette. Teorierne, som den sportspsykologiske konsulent baserer sin intervention på, leder hans eller hendes vurderinger, refleksioner og handlinger (Lane \& Corrie, 2006). Som en del af det sportspsykologiske hold i Team Danmark blev mine ydelser guidet af en systematisk og sammenhængende professionel filosofi (Henriksen, Hansen, \& Diment, 2011). Den professionelle filosofi består af fem niveauer: a) basale overbevisninger og værdier; b) interventionsteorier (kognitiv adfærdspsykologi, økologiskpsykologi og eksistentielpsykologi); c) målsætningen med sportspsykologiske interventioner; d) indholdet af interventionen struktureret af "Team Danmarks sportspsykologiske model"; og e) sportspsykologiske servicer og metoder. I deen med modellen er, at en velfunderet intervention behøver konsistens mellem disse fem niveauer. Før jeg indtrådte $i$ klubben, og baseret på mine egne erfaringer fra fodbold, var jeg bevidst opmærksom på min egen professionelle baggrund, bias, viden og interesse i selvreflektion (McGannon \& Johnson, 2009). Refleksivitet gør det muligt for sportspsykologiske konsulenter at bevæge sig ud over blot at yde service på samme måde til alle, og i stedet benytte mere kulturelt sensitive fremgangsmåder (McGannon \& Schinke, 2015). I dette tilfælde ville jeg opbygge forhold til og optjene tillid fra spillerne og trænerne i klubben, og derfor var jeg opmærksom på at præsentere mig selv som neutral, rolig og sikker. I henhold til min sociale position (f.eks. veluddannet akademiker) var jeg opmærksom på, hvordan jeg kommunikerede og prøvede at levere simple og forståelige beskeder til spillerne, trænerne og staben. For at stimulere til refleksivitet opfatter jeg det som anvendeligt at arbejde med forskellige sportsgrene på samme tid. Når man ikke udelukkende arbejder med én sport såsom fodbold, er det muligt at hente erfaring fra andre sportsgrene og således "ikke blive blind" i den ene kontekst, som man arbejder i. Konsulenten skal være i stand til at reflektere over omsættelighed med henhold til løsninger, erfaringer og forskelle fra en kontekst til en anden. En almindelig funktion ved den professionelle udvikling i Team Danmark er at modtage supervision fra kollegaer og en ekstern psykolog om cases (f.eks. vanskeligheder $\mathrm{i}$ det daglige arbejde med spillerne). Supervision giver også muligheden for, at mine kollegaer kan udfordre mig og mine valg. Disse sessioner giver, for mig, en anledning til at forblive refleksiv over min egen professionelle udvikling og at åbne op for nye vinkler, som kan udvikle min service.

\section{Beskrivelse af klubben}

Fodboldklubben, som denne artikel er baseret på, var en topklub, der har vundet tre danske mesterskaber og tre pokaltitler. Klubben bestod af to afdelinger: en frivillig amatørafdeling for en bred vifte af fodboldspillere, og en professionel eliteafdeling for mandlige ungdomshold (der strækker sig fra U13 år tilU19 år såvel som et professionelt seniorelite hold. Klubben havde fuldtidstrænere til hvert ungdomshold; de fleste af dem var tidligere spillere fra klubben, hvilket kan opfattes som et udtryk for, at klubben troede på gamle værdier. Nærværende case involverer det professionelle seniorhold, hvilket udgør sin egen sektion i klubben og spillede i den danske Superliga. Holdet bestod af ca. 25 spillere og 12 medarbejdere (der spænder fra holdledere til trænere og sportschefer). Klubben omstrukturerede deres spillestil på det tidspunkt og havde tidligere fyret en sportschef og ansat en ny i tråd med deres nye spillestil. Yderligere havde klubben ansat to relativt nye og uerfarne trænere (en af dem en tidligere spiller og den anden en ungdomstræner og fysisktræner) seks måneder tidligere og var i gang med at ændre værdierne og kulturen i klubben. Tilsvarende de fleste andre Superliga-klubber på det tidspunkt, havde klubben ikke tidligere integreret sportspsykologi i deres professionelle afdeling. Klubben var en del af en større virksomhed, som er inddelt i fem sammenhængende kommercielle områder: professionel fodbold (den professionelle afdeling), vært for koncerter, events, seminarer og golfarrangementer. Disse kommercielle områder kan ses som artefakter som fremhæver, hvordan fodbold er kommercielt, professionelt, og indlejret $\mathrm{i}$ forretningsværdier - selvom klubben i internationale sammenhænge kan betegnes som en lille fodboldklub. En bestyrelse og en administrerende direktør styrede de fem kommercielle områder, og bestyrelsesformanden ejede det meste af klubben og administrerede endvidere flere andre virksomheder indenfor elektriske varer og detailhandel. 


\section{Sport and Exercise Psychology}

\section{Beskrivelse af det sportspsykologiske program}

Fase 1. At få adgang og opbygge forhold

Jeg startede med at arbejde i klubben i vinteren 2011. Klubben kontaktede mig, og med udgangspunkt i anbefalinger, såvel som personlige samtaler med en HRkonsulent, en leder for den kommercielle del af klubben og cheftræneren, takkede jeg ja til den nye stilling i oktober 2011. De første par dage i klubben bestod af møder med ledelsen og andre medarbejdere i klubben. Ledelsen iværksatte møderne, og formålet var at informere mig om klubbens organisationsstruktur. I denne fase stræbte jeg efter en neutral og distanceret observerende rolle. Min indtræden i klubben var desuden dirigeret af mine tidligere erfaringer fra mit arbejde som sportspsykologisk konsulent i professionel fodbold. Jeg var opmærksom på fodbold som forretning med dets muligheder og begrænsninger. Og ligeledes var mine organisatoriske og personlige interesser afhængig af $\min$ positionering og egne fordomme i processen (Anderson, Knowles, \& Gilbourne, 2004).

\section{Fase 2. Observation og analyse}

Denne fase var karakteriseret ved at blive introduceret til truppen, den professionelle afdeling og staben. Baseret på tidligere møder med ledelsen og trænere, var denne fase kendetegnet ved observation og analyse af klubbens kultur og holdet over en periode på to måneder. Mine overordnede ansvarsområder (præciseret af ledelsen) beroede på et langsigtet perspektiv med henhold til at gøre sportspsykologi til en væsentlig del af kulturen i klubben. I løbet af den første uge gjorde jeg holdet opmærksom på min rolle, og jeg blev introduceret til staben og informeret om organisationen og de organisatoriske ændringer, som blev foretaget i den professionelle afdeling. Jeg indledte mit arbejde med at analysere de forskellige individer og deres rolle i miljøet, i tråd med begreberne fra Henriksen et al. (2010). Derved opnåede jeg en forståelse for relationer, kommunikation og nøglepersoner i miljøet. Udover at analysere miljøet observerede jeg træningssessioner, diskuterede sportspsykologi med trænerne og deltog i nationale kampe samt Europa League kampe. I løbet af disse kampe observerede jeg trænernes og spillernes adfærd. Observationerne var i overensstemmelse med in situ observationer af den sociale praksis (Tanggaard, 2006). Hen ad vejen fik jeg "styr på", hvad der skulle fokuseres på. I slutningen af denne fase foreslog jeg fire forskellige, men forbundene komponenter til et sportspsykologisk program i klubben: For det første startede jeg med at udvikle sammenhæng mellem ungdoms- og seniorafdelingen. På det tidspunkt arbejdede ungdomsafdelingen ikke med sportspsykologi, og de ungdomsspillere, som succesfuldt klarede transitionen til seniorholdet, havde behov for nogle psykologiske færdigheder for at håndtere og udvikle sig på seniorniveau. Den primære opgave for talentudviklingsmiljøet er at udstyre atleter med en holistisk færdighedspakke indholdene: "et bredt udvalg af kognitive, perceptuelle og motoriske færdigheder... som viser sig at være forskellen mellem de bedste og næstbedste udøvere på et senere stadie" (Martindale \& Mortimer, 2011, s.71). For det andet påbegyndte jeg individuelle konsultationer med et antal af interesserede spillere (seks unge og en erfaren). Vel vidende at sportspsykologi var et nyt udviklingsområde for spillere, blev jeg nødt til at sælge sportspsykologiens til spillerne. For det tredje var begge trænere relativt nye trænere på dette niveau og interesseret $\mathrm{i}$ gruppesessioner med henblik på at arbejde med beslutningstagen og håndtering af stress. At træne på topniveau involverer hårde beslutninger og et stort pres fra fans, medierne og organisationen hvis eller når den ikke leverer de forventede resultater (Bruinshoofd \& ter Weel, 2003). For det fjerde begyndte jeg sessioner med gruppen (f.eks. defensive spillere) og på holdniveau (hele holdet) omhandlende kommunikation og psykologisk momentum (Larsen \& Henriksen, 2014). Psykologisk momentum er forbundet med præstationsevne, og er defineret som en "positiv eller negativ ændring i kognition, fysiologi, affekt og adfærd forårsaget af en fremskyndet begivenhed eller en serie af begivenheder, som vil resultere i et skifte i præstationsevnen" (Taylor \& Demick, 1994, s. 51) for en gruppe eller et hold.

Fase 3. Påbegynde programmet og træeningslejren Efterfølgende observationerne og analysen af miljøet og organisationen indledte jeg programmet $\mathrm{i}$ januar 2012, hvilket betød, at jeg arbejdede tre måneder i en neutral og observerende rolle. Det overordnede mål var at styre de fire komponenter i det sportspsykologiske program. Jeg deltog regelmæssigt i træningssessionerne, kampene og møderne og var ansvarlig for det sportspsykologiske program. De individuelle sessioner med spillerne og gruppesessionerne med træneren blev iværksat. For at etablere relationer og opbygge tillid fokuserede jeg på kontinuiteten ved min service, og forklarede hvad spillerne kunne forvente af de individuelle sessioner, såvel som gruppesessionerne. Jeg udviste respekt, bibeholdte åben og konstruktiv kommunikation og forsikrede om fortrolighed i mine sessioner. Informationer fra sessionerne ville kun blive diskuteret med den respektive spillers tilladelse.

I slutningen af januar 2012 rejste holdet til Sydeuropa på en to ugers træningslejr. Formålet, på denne træningslejr, var at starte med at arbejde med psykologiske momentum og kommunikation i grupper (forsvarsspillere og målmænd, midtbanespillere, angribere). Jeg sigtede specifikt efter at stimulere spillerne til at reflektere over psykologisk momentum og kommunikation i løbet af kampe: a) Jeg ville have spillerne til at forstå dem selv og deres læringsproces; b) at være opmærksom på deres egen måde at ræsonnere på; c) at lære at reflektere over tidligere læringsoplevelser; d) at udfordre deres egne etablerede adfærdsmønstre og meningsstrukturer i deres problemløsningsindsatser; e) at være i stand til at lede efter nye veje til at omdirigere deres problemløsende adfærd på en mere effektiv måde. For at dele erfaringer med psykologisk momentum og kommunikation mellem for eksempel de individuelle spillere i forsvaret fokuserede jeg på en tilgang, hvor formålet var at få spillerne til at reflektere over og lytte til beretninger og historier fra hinanden (Windsor, Barker, \& McCarthy, 2011). Spillerne og staben, der var involveret, var positive og åbne overfor at adressere psykologiske problemer i fodbold, såvel som personlige problemer. Træningslejeren var et omdrejningspunkt for at iværksætte de fire komponenter af programmet og tjente som et fundament for at opretholde disse komponenter i løbet af ugerne og i løbet af sæsonen. Som spillerne blev mere vant til min rolle i klubben steg antallet af spillere, som tog del i de individuelle sessioner. Forøgelsen i fortrolighed syntes at være relateret til min tid i klubben, såvel som min konsistens i min kommunikation og adfærd over for spillerne. Baseret på min involvering i miljøet lærte spillerne mig at kende og kontaktede mig i højere grad for at diskutere psykologiske problemer $\mathrm{i}$ forbindelse med at være en fodboldspiller, problem relateret til kampe, men også personlige problemer. Gruppesessionerne med trænere tog udgangspunkt i en månedlig mundtlig evaluering, som gradvist udviklede sig til evaluering af forberedelse og præstationsevne under træning og kampe. Jeg fortsatte med at prøve at tilpasse programmet til 
trænernes specifikke behov og normerne i klubben. Desuden var denne fase $\mathrm{i}$ begyndelse af sæsonen og placeringen i ligatabellen ikke et problem.

\section{Fase 4. "Krise" og afslutningen på programmet}

Som sæsonen skred frem leverede holdet flere middelmådige præstationer og blev slået af lavererangerende hold. Holdet styrtdykkede til bunden af ligatabellen og trænernes præstation blev ikke vurderet tilstrækkelig nok til at opnå klubbens målsætning. Cheftræneren blev fyret. Efterfølgende fyringen af træneren overtog sportschefen holdet resten af sæsonen. Denne specifikke organisatoriske ændring og kritiske transition i den anden halvdel af sæsonen havde konsekvenser for det sportspsykologiske program i klubben, og havde indirekte betydning med hensyn til min involvering (Wagstaff et al., 2015). Sportschefen stoppede gruppesessionerne, fordi han pludselig var mindre interesseret i sportspsykologi og mere fokuseret på at overleve. Sportschefen ville have spillerne til at koncentrere sig om at præstere. "For meget snak kunne få spillerne til at miste fokus". Han var under pres og varetog to job (cheftræner og sportschef). Logikken i hans ræsonnement syntes at være at opbygningen af opmærksomhed, relationer og refleksion nu var et problem snarere end en løsning. Dette var tidligere væsentlige udviklingsområder (fremhævet få måneder tidligere), hvilke nu blev afbrudt på grund af frygt for nedrykning og på grund af presset fra medierne, fans, ledelsen og interessenter. Min rolle ændrede sig pludselig fra sikker til usikker. På trods af min indsats og argumenter for at bibeholde programmets nuværende struktur, oplevede jeg, at det var som om, at drømmen brast om at implementere sportspsykologi som en del af klubbens kultur. Jeg indså for første gang at, i professionel sport overtrumfer resultater processen. Holdet undgik med nød og næppe nedrykning og forblev i den danske Superliga. I slutningen af året blev en ny træner udnævnt. Til trods for interessen hos den $\varnothing v e r s t e$ del af ledelsen (at sportspsykologi var en vigtig del af klubbens kultur) og min etablerede rolle i organisationen, fulgte sportschefen anmodningen fra den nye træner, som ville medbringe sin egen stab, og derfor blev det sportspsykologiske program og min ansættelse afsluttet.

\section{Refleksioner over kultur og konsultationsfilosofi}

I denne artikel delte jeg mine erfaringer med at udvikle og implementere et sportspsykologisk program i en dansk professionel fodboldklub. Fifer et al. (2008) fremhæver vigtigheden ved at være opmærksom på konteksten, hvori man arbejder, organisationens politik, holdet og stabens dynamik samt mængden af støtte, som er til rådighed. Den store mængde forskning udført af Wagstaff et al. (2015) indikerer, at organisatoriske ændringer har indflydelse på præstationen på banen. Nærværende artikel tyder på, at en fodboldklub i krisesituationer har flere "logikker", der opererer i den samme organisation. Hver subkultur (f.eks. blandt henholdsvis trænere og ledelsen) har forskellige værdier og antagelser. Jeg har præsenteret et eksempel på en forretningslogik, der har tilsidesat sportens udviklingslogik. Sideløbende har forskere i kulturel sportspsykologi fremhævet vigtigheden ved, at sportspsykologiske konsulenter er opmærksom på sin professionelle baggrund, bias, viden og interesser på en selvreflekterende måde (McGannon \& Johnson, 2009). I lang tid har konsulenter og forskere indenfor sportspsykologi vendt det blinde øje til de potentielle kompleksiteter, der kan være forbundet med integration af kulturelle aspekter i sportspsykologi (Schinke \& Moore, 2011). I denne artikel har jeg rettet opmærksomheden mod behovet for, at den sportspsykologiske konsulent integrerer begreberne som selvrefleksivitet og kulturel sensitivitet i sine ydelser og filosofi, når han eller hun bliver hyret ind i professionel sportsorganisation. Det er nødvendigt at have et øje på forskellige "logikker", der opererer i organisationen. I gode tider eksisterer de fredeligt side om side, og det kan fremstå som en stærk og sammenhængende kultur, men i "krisetider" og modgang har de svært ved at sameksistere og i fodbold vil "quick fixes" tilsyneladende råde. Fodboldkultur er kendetegnende ved "kortsigtethed" med hensyn til et behov for at vinde næste kamp, undgå nedrykning og at overleve for enhver pris og derved tilfredsstille forventninger fra sponsorer og fans. Ved indtrædelsen i klubben var jeg bevidst om og arbejdede ud fra en sammenhængende filosofi, og justerede min service i henhold til normer og relationer med trænere samt spillere. Til trods for en sammenhængende filosofi var det ikke nok at være effektiv i klubben i krise (f.eks. den nedre del af ligatabellen og presset fra medierne). Ledelsen har en magtposition i klubben, og ifølge Schein (2010) har sådan en position en stor indflydelse på udviklingen af kulturen. I midlertid reagerer henholdsvis trænere og ledere i en professionel klub ud fra to forskellige logikker og standpunkter. I en krise reagerer den øverste ledelse på kritiske hændelser med udgangspunkt i økonomi (Storm, 2012). En topledelse er nødt til at vise medierne, interessenter og andre, at de er stærke som organisation og reagerer på sådanne situationer, selvom disse handlinger er i kontrast til sportsafdelingens logik. En sportslig afdeling (og konsulenten som en del af den sportslige afdeling) er interesseret $i$, opmærksom på og arbejder med et holds udvikling og præstation. Kritiske hændelser gør topledelsen mere påvirkelig overfor forandringer og ledelsen vil sende et stærkt signal om klubbens prioriteter og målsætninger i krisetider. Imidlertid indebærer disse signaler ofte ændringer $\mathrm{i}$ den sportslige afdeling. Sportspsykologiske konsulenter er nødt til at være opmærksom på, hvordan resultater kan påvirke organisatoriske ændringer (f.eks. udskifte trænere), og hvordan organisatoriske ændringer kan påvirke hans eller hendes service i professionelle sportsorganisationer. Sportspsykologiske konsulenter, der indtræder $\mathrm{i}$ en professionel organisation, har behov for at have politisk forståelse og er nødt til at vide, at ændringer vil opstå, når resultaterne er dårlige. I min optik kan det derfor være nødvendigt at sportspsykologiske konsulenter sikrer sig en langsigtet kontrakt, og dermed sikrer sin egen position, inden tiltrædelsen af stillingen, eller blive ansat på deltid på akademiet. Selvom trænere bliver skiftet i fodbold, kan sportspsykologiske konsulenter dermed være mindre påvirket af ændringer og være i stand til at støtte udvikling og skabe langsigtede resultater i professionelle klubber. 
Anderson, A., Knowles, Z., \& Gilbourne, D. (2004). Reflective practice for sport psychologists: Concepts, models, practical implications, and thoughts on dissemination. The Sport Psychologist, 18, 188-203.

Bruinshoofd, A., \& ter Weel, B. (2003) Manager to go? Performance dips reconsidered with evidence from Dutch football, European J ournal of Operational Research, 148, 233-246.

Cruickshank, A., \& Collins, D. (2012). Change management: The case of elite sport performance team. J ournal of Change Management, 12, 209-229. doi: 10.1080/14697017.2011.632379

Fifer, A., Henschen, K., Gould, D., \& Ravizza, K. (2008). What works when working with athletes. The Sport Psychologist, 22, 356-377.

Fletcher, D., \& Arnold, R. (2011). A qualitative study of performance leadership and management in elite sport, Journal of Applied Sport Psychology, 23, 223242. doi: http://dx.doi.org/10.1080/10413200.2011.559184

Fletcher, D., \& Wagstaff, C.R.D. (2009) Organizational psychology in elite sport: its emergence, application and future. Psychology of Sport and Exercise, 10, 427-434. doi: http://dx.doi.org/10.1016/j. psychsport.2009.03.009

Harwood, C., \& Steptoe, K. (2013). The integration of single case designs in coaching contexts: A commentary for applied sport psychologists. Journal of Applied Sport Psychology, 25, 167-174. doi: 10.1080/10413200.2012.690361

Henriksen, K., Hansen, J., \& Diment, G. (2011) Professional philosophy: Inside the delivery of sport psychology service at Team Denmark. Sport Science Review, 20, 5-21. doi: 10.2478/v10237-011-0043-6

Henriksen, K., Stambulova, N., \& Roessler, K. K. (2010). A holistic approach to athletic talent development environments: A successful sailing milieu. Psychology of Sport and Exercise, 11, 212-222. doi: 10.1016/j.psychsport.2009.10.005

Johnson, U., Andersson, K., \& Fallby, J. (2011). Sport psychology consulting among Swedish premier soccer coaches. International J ournal of Sport and Exercise Psychology, 9, 308-322. doi: 10.1080/1612197X.2011.623455

Lane, D. A., \& Corrie, S. (2006). The modern scientistpractitioner: A guide to practice in psychology. London: Routledge.

Larsen, C. H., \& Henriksen, K. (2014). Psychological momentum in team sport: An intervention program in professional soccer. Sport Science Review, 24, 2740. doi: $10.1515 / \mathrm{ssr}-2015-0007$

Martindale, R. J. J., \& Mortimer, P. (2011). Talent development environments: Key considerations for effective practice. In D. Collins, A. Button, \& H. Richards (Eds.), Performance psychology: A practitioner's guide (pp. 65-84). Kidlington: Elsevier.

McGannon, K. R., \&Johnson, C. R. (2009). Strategies for reflective cultural sport psychology research. In R. J.
Schinke \& S. J. Hanrahan (Eds.), Cultural sport psychology (pp. 57-75). Champaign, IL: Human Kinetics.

McGannon, K. R., \& Schinke, R. J. (2015). Situating the subculture of sport, physical activity and critical approaches. In R. J. Schinke \& K. R. McGannon (Eds.), The psychology of sub culture in sport and physical activity: Critical approaches (pp. 1-14). East Sussex, UK: Psychology Press.

Mielke, D. (2007). Coaching experience, playing experience and coaching tenure. International J ournal of Sports Science and Coaching, 2, 105-108.

Moran, J. W., \& Brightman, B.K. (2001). Leading organizational change. Career development international, 6, 111-118. doi: http://dx.doi.org/10.1108/13620430110383438

Nesti, M. (2010). Psychology in football. New York: Routledge.

Nesti, M., Littlewood, M., O'Halloran, L., Eubank, M., \& Richardson, D. (2012). Critical moments in elite premiership football: Who do you think you are? Physical Culture and Sport. Studies and Research, 56, 23-32. doi: 10.2478/v10141-012-0027-y

Schein, E. H. (2010). Organizational culture and leadership. San Francisco: John Wiley \& Sons.

Schinke, R. J., \& Moore, Z. E. (2011). Culturally informed sport psychology: Introduction to the special issue. Journal of Clinical Sport Psychology, 5, 283-294. Retrieved from http://journals. humankinetics.com/jcsp

Storm, R. (2012). Krisen kradser i dansk fodbold [A looming crisis in Danish football]. The Danish Institute for Sport Studies. Retrieved from http://www.idan.dk/Nyheder/a235superligatal.aspx

Tanggaard, L. (2006). A psychological field study of learning: Analysis of methodological aspects. Nordic Psychology, 58, 196-214. doi: http://dx.doi.org/10.1027/1901-2276.58.3.196

Taylor, J., \& Demick, A. (1994). A multidimensional model of momentum in sports. Journal of Applied Sport Psychology, 6, 51-70. doi: 10.1080/10413209408406465

Tipsbladet (2016, June). Danish sports and betting magazine. Retrieved from: http://www.tipsbladet.dk/nyhed/superliga/traenerka russel-flest-traenerskifter-i-hobro-ob-og-viborg

Wagstaff, C. R. D., \& Larner, R. J. (2015). A review of organizational psychology in elite performance domains: Recent developments and future directions. In S. D. Mellalieu \& S. Hanton (Eds.), Contemporary reviews in sport psychology (pp. 91110). London, UK: Routledge.

Windsor, P. M., Barker, J., \& McCarthy, P. (2011). Doing sport psychology: Personal-disclosure mutual sharing in professional football. The Sport Psychologist, 25, 94-114. 